\title{
Production of a Phytotoxic Compound, 3-Phenylpropionic Acid by a Bacterial Endophyte, Arthrobacter humicola YC6002 Isolated from the Root of Zoysia japonica
}

\author{
Eu Jin Chung, Joo Hwang Park ${ }^{2}$, Tae Soon Park ${ }^{2}$, Jong-Woong Ahn ${ }^{3}$ and Young Ryun Chung ${ }^{1,2 *}$ \\ ${ }^{1}$ Department of Research \& Development, JGreen Inc., Changnyeong 635-806, Korea \\ ${ }^{2}$ Division of Applied Life Science (BK 21), PMBBRC, Gyeongsang National University, Jinju 660-701, Korea \\ ${ }^{3}$ Division of Marine Environment \& Bioscience, Korea Maritime University, Busan 606-791, Korea \\ (Received on March 2, 2010; Accepted on July 12, 2010)
}

\begin{abstract}
An endophytic bacterial strain, Arthrobacter humicola YC6002, was isolated from a surface sterilized root of Korean turf grass (Zoysia japonica) collected from Jinju, Korea. This strain showed inhibitory effect on germination and shoot growth of radish. The inhibition of germination and shoot growth of radish seeds varied depending on the age of culture and the temperature at which it was incubated. The culture filtrate of 1/10strength Tryptic Soy Broth medium, incubated for 48 hours at $30^{\circ} \mathrm{C}$, showed the highest inhibitory effect on radish seed germination and shoot growth $(92 \%$ inhibition as compared to control). The active compound with seed germination and shoot growth inhibition was purified and identified as 3-phenylpropionic acid. The purified compound had $53 \%$ and $93 \%$ inhibitory effect on seed germination and shoot growth of radish for 500 and $1000 \mathrm{ppm}$ solutions, respectively.
\end{abstract}

Keywords : endophyte, phytotoxic, Arthrobacter humicola, 3-phenypropionic acid

Many endophytic bacteria inhabiting in the tissue of host plants have been studied for their beneficial effects on growth and plant yield of host plant, maintenance and protection of plant health, pollution control and phytoremediation (Brooks et al., 1994; Miller et al., 1998; Ryan et al., 2008; Siciliano et al., 2001). These symbiotic interactions of endophytes with host plants are due to their ability to secrete a wide range of secondary metabolites (Ryan et al., 2008; Strobel and Daisy, 2003) including antibiotics (Strobel et al., 2004), volatile organic compounds (Ryu et al., 2003), antifungal (Beck et al., 2003; Strobel et al., 2004), and insecticidal agents (Azevedo et al., 2000). Endophytic bacteria with antifungal activity have been considered as biocontrol agents against phytopathogens (Lee et al., 2008; Liu et al., 2007; Rosenblueth and Martínez-Romero, 2006). Recently, it

\footnotetext{
*Corresponding author.

Phone) +82-55-751-5945, FAX) +82-55-759-0187

E-mail)yrchung@gnu.ac.kr
}

was found that bacteria such as Burkholderia spp., and Pseudomonas spp. demonstrate antimicrobial activity as well as cytotoxic activity by producing both antifungal and phytotoxic metabolites (Andreote et al., 2009; Chung et al., 2008; Duijff et al., 1997; Patel et al., 2009; Ramasamy et al., 2009).

The endophytic strain of Pseudomonas brassicacearum YC5480 produces antifungal and phytotoxic compounds identified as 2,4-diacetylphloroglucinol (DAPG) and 2,4,6trihydroxyacetophenone (THA) (Chung et al., 2008). The THA and DAPG toxic to plant growth produced by endophytic bacteria could be used in the eco-friendly management of parasitic weeds by preventing early growth or seed germination of the weeds (Chung et al., 2008; Vurro et al., 2009). The isolates of Pseudomonas syringae also produced phytotoxic compounds such as syringomycin and syringopeptin of which mode of action, regulation and biosynthesis by peptide and polyketide synthetases were elucidated (Bender et al., 1999). Some metabolites with phytotoxic activity produced by rhizobacteria or fungi reduced the number of normal seedlings of lettuce and a novel toxin such as phyllostictine inhibited germ tube elongation and seed germination of a hemp broomrape Orobanche ramosa and field dodder Cuscuta campestris (Carvalho et al., 2007; Vurro et al., 2009).

In this study, we isolated a strain of Arthrobacter sp. YC6002 with phytotoxic activity and identified it based on morphological, biochemical characteristics and 16S rRNA gene sequence analysis. The structure and activity of a phytotoxic substance produced by the strain was also determined.

\section{Materials and Methods}

Isolation of endophytic bacteria. Endophytic bacteria were isolated from roots of various plant samples, collected from Jinju and Sacheon area, Korea (Table 1) (Chung et al., 2008). The roots were rinsed with tap water and surface sterilized with $1 \% \mathrm{NaOCl}$ for 10 min followed by washing 
Table 1. Endophytic bacterial strains isolated from various plant roots and inhibitory activity of radish seed germination

\begin{tabular}{cllc}
\hline \hline Strains & Locality & Host plant & $\begin{array}{c}\text { Inhibition of radish } \\
\text { germination }\end{array}$ \\
\cline { 3 - 4 } & & & $1 / 2$ TSB \\
\hline YC5956 & Sacheon & Glycine max & - \\
YC5957 & Sacheon & Glycine max & ++ \\
YC5958 & Sacheon & Glycine max & + \\
YC5965 & Sacheon & Glycine max & ++ \\
YC5975 & Jinju & Zea mays & - \\
YC5982 & Jinju & Brassica pekinensis & - \\
YC5983 & Jinju & Brassica pekinensis & - \\
YC6001 & Jinju & Zoysiajaponica & - \\
YC6002 & Jinju & Zoysiajaponica & +++ \\
YC6006 & Jinju & Zoysiajaponica & + \\
\hline
\end{tabular}

${ }^{a}$ The culture filtrate was used to test the radish seed germination inhibitory activity. Five seeds of radish in three replications were placed on a piece of sterile Kim-Wipe tissue $(2 \times 2 \mathrm{~cm})$ in a plastic plate loaded with $0.5 \mathrm{ml}$ culture filtrate for 5 days under fluorescent light. $-; 0-40 \%$ inhibition, $+; 40-60 \%$ inhibition, $++; 60-80 \%$ inhibition, +++; 80-100\% inhibition. 1/2 TSB; 1/2-strength Tryptic Soy Broth.

with $70 \%$ ethanol for about 10 seconds. Root pieces were rinsed again in sterile distilled water (SDW), blotted dry on a sterile filter paper, placed on 1/10-strength Tryptic Soy Agar (TSA, Difco, USA) and incubated at $28^{\circ} \mathrm{C}$ for bacterial growth to check the surface contamination. After confirmation of the surface sterility of root segments, $1.0 \mathrm{~g}$ of dried plant root was ground in $9.0 \mathrm{ml}$ of phosphate buffer ( $\mathrm{pH} 7.2$ ) using pre-sterilized mortar and pestle under aseptic condition. The extract was serially diluted $10^{3}-10^{5}$ times using phosphate buffer and $100 \mu \mathrm{l}$ of diluted solution was applied on the $1 / 10 \mathrm{TSA}$ plates. After incubation at $28^{\circ} \mathrm{C}$ for 3 days, bacterial strains with inhibitory activity on radish (Raphanus sativus, Nongwoo Bio Co. Ltd., Korea) seed germination were selected and purified strains were maintained on $1 / 10 \mathrm{TSA}$ at $4^{\circ} \mathrm{C}$ for further studies.

Seed germination inhibitory activity. For the test of seed germination inhibitory activity, the culture filtrate of bacterial strains prepared by centrifugation $(\times 9000 \mathrm{~g}, 10 \mathrm{~min})$ was applied to radish seeds surface-sterilized with $1 \%$ $\mathrm{NaOCl}$ for $5 \mathrm{~min}$. Five seeds of radish were placed on a piece of sterile Kim-Wipe tissue $(2 \times 2 \mathrm{~cm})$ soaked with 0.5 $\mathrm{ml}$ culture filtrate in a plastic plate. The plates in 3 replications were incubated for 5 days $(120 \mathrm{~h})$ at $25^{\circ} \mathrm{C}$ under the fluorescent light (65 Lux) and the percent germination of radish seeds and growth of sprouts were investigated. Concentration for active compound dissolved in $1 \mathrm{ml}$ of methanol was loaded on a piece of sterile filter paper $(2 \times 2$ $\mathrm{cm})$. After drying completely, five seeds of radish were placed on the piece of sterile filter paper soaked with $1 \mathrm{ml}$ of distilled water in a plastic plate. The plates in 3 replications were incubated for 5 days at $25^{\circ} \mathrm{C}$ under fluorescent light. Methanol and sterile water were used as untreated control.

Mass production of seed germination inhibitory compounds. To standardize mass production of the active compound, following culture media were tested: 1/10strength Tryptic Soy Broth (TSB), minimal chitin medium (colloidal chitin $5.0 \mathrm{~g}, \mathrm{KH}_{2} \mathrm{PO}_{4} 0.5 \mathrm{~g}, \mathrm{~K}_{2} \mathrm{HPO}_{4} 0.5 \mathrm{~g}, \mathrm{ZnSO}_{4}$ $0.5 \mathrm{~g}, \mathrm{FeSO}_{4} \cdot 7 \mathrm{H}_{2} \mathrm{O} 0.01 \mathrm{~g}$ in $1 \mathrm{~L} \mathrm{DW}$ ) (Singh et al., 1999), Czapek-dox broth (CDB, Difco), R2A broth (yeast extract $0.5 \mathrm{~g}$, proteose peptone NO. $30.5 \mathrm{~g}$, casamino acid $0.5 \mathrm{~g}$, dextrose $0.5 \mathrm{~g}$, soluble starch $0.5 \mathrm{~g}$, sodium pyruvate $0.3 \mathrm{~g}$, $\mathrm{K}_{2} \mathrm{HPO}_{4} 0.3 \mathrm{~g}, \mathrm{MgSO}_{4} 0.05 \mathrm{~g}$ in $1 \mathrm{~L} \mathrm{DW}$ ), glucose starch broth (GSB) (soluble starch $5.0 \mathrm{~g}$, glucose $5.0 \mathrm{~g}$, aspartic acid $0.5 \mathrm{~g}, \mathrm{~K}_{2} \mathrm{HPO}_{4} 0.5 \mathrm{~g}, \mathrm{MgSO}_{4} 0.5 \mathrm{~g}$ and $\mathrm{FeSO}_{4} 0.01 \mathrm{~g}$ in $1 \mathrm{~L} \mathrm{DW}$ ), soybean meal flour medium (SMF) (yeast extract $4.0 \mathrm{~g}$, beef extract $1.0 \mathrm{~g}$, soluble starch $20.0 \mathrm{~g}$, soybean meal $25.0 \mathrm{~g}$, glucose $5.0 \mathrm{~g}, \mathrm{~K}_{2} \mathrm{HPO}_{4} 0.1 \mathrm{~g}, \mathrm{NaCl} 2.0 \mathrm{~g}$ in $1 \mathrm{~L}$ DW), soytone glucose broth (SGB) (glucose $15.0 \mathrm{~g}$, soytone $15.0 \mathrm{~g}$, yeast extract $5.0 \mathrm{~g}$, casamino acid $1.0 \mathrm{~g}, \mathrm{~K}_{2} \mathrm{HPO}_{4} 0.1$ g, $\mathrm{NaCl} 2.0 \mathrm{~g}$ and $\mathrm{FeSO}_{4} \cdot\left(\mathrm{NH}_{4}\right)_{2} \mathrm{SO}_{4} \cdot 6 \mathrm{H}_{2} \mathrm{O} 0.05 \mathrm{~g}$ and $\mathrm{MgSO}_{4} \cdot 7 \mathrm{H}_{2} \mathrm{O} 0.2 \mathrm{~g}$ in $1 \mathrm{~L} \mathrm{DW}$ ) and M523 broth (sucrose $1.0 \mathrm{~g}$, casamino acid $8.0 \mathrm{~g}$, yeast extract $4.0 \mathrm{~g}$ and $\mathrm{MgSO}_{4}$ $0.3 \mathrm{~g}$ in $1 \mathrm{~L} \mathrm{DW}$ ) (Chung et al., 2008). Each medium (500 $\mathrm{ml}$ ) was incubated with the $5 \mathrm{ml}$ one-day old bacterial culture for 3 days at $30^{\circ} \mathrm{C}$ on a rotary shaker (approximately $180 \mathrm{rpm}$ ). Among these culture media, the culture filtrate of 1/10 TSB had shown the strongest inhibitory effect on radish seed germination. Therefore, 1/10 TSB medium was used for mass production of the active metabolite.

Isolation and purification of a seed germination inhibitory compound. Mass culture of strain YC6002 was carried out in a $500 \mathrm{~L}$ fermentor (KF-500, KoBioTech, Korea) with a working volume of $100 \mathrm{~L}$. The specific culture conditions $\left(30^{\circ} \mathrm{C}, \mathrm{pH} 7.0\right.$ and 0.6 volume/medium volume/min aeration) and impeller speed $(300 \mathrm{rpm})$ was maintained throughout the incubation. After 2 days culture, the broth culture (54 liters) was centrifuged using continuous centrifugation system at $9000 \mathrm{~g}$ for $10 \mathrm{~min}$ to remove the bacterial cells. The cell-free supernatant was concentrated to 1 liter under reduced pressure and the residual solution was extracted twice with an equal volume of ethyl acetate (EtOAc). The extracts combined were concentrated under reduced pressure to give $1.5 \mathrm{~g}$ of brown oil. This brown oil was then separated into 5 fractions by a silica gel column using different proportions of $\mathrm{CH}_{2} \mathrm{Cl}_{2}$, acetone and $\mathrm{MeOH}$. The bioactive fraction 2, eluted with $\mathrm{CH}_{2} \mathrm{Cl}_{2}$ and acetone (95:5), was again fractionated by silica gel column using a step 


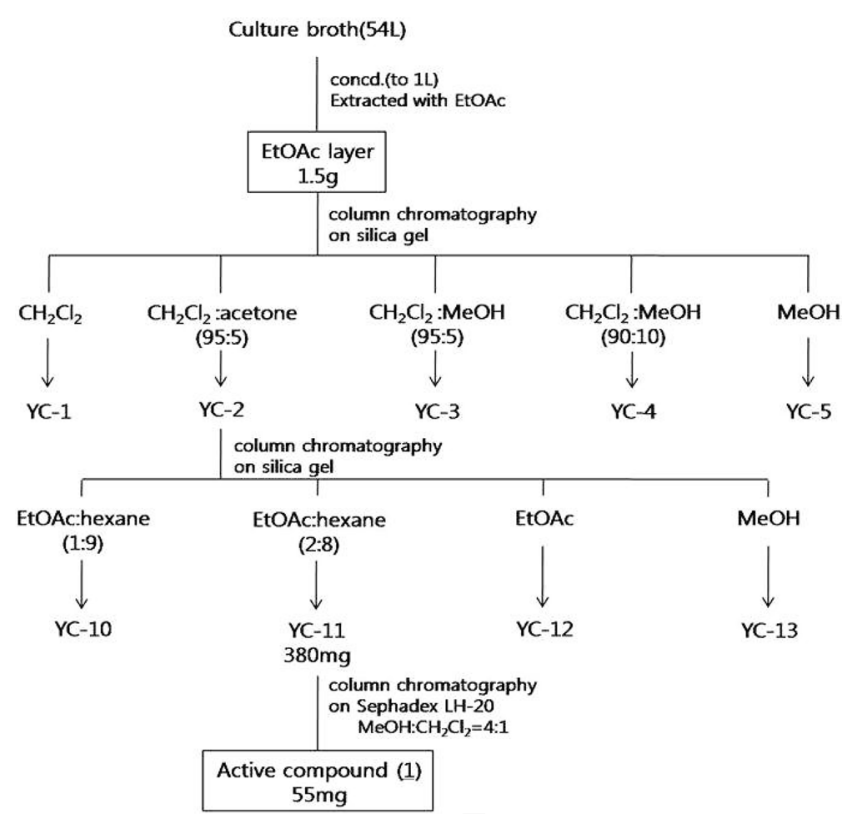

Fig. 1. Separation procedure of the inhibitory compound from the culture filtrate of Arthrobacter humicola YC6002.

gradient elution of different n-hexane and EtOAc combinations. The bioactive fraction 7 (380 mg), eluted with $\mathrm{n}$ hexane-EtOAc 4:1, was further purified by a Sephadex LH20 column chromatography (using $\mathrm{CH}_{2} \mathrm{Cl}_{2}$ and $\mathrm{MeOH}$ in 1:4 ratio as mobile phase) to obtain $55 \mathrm{mg}$ of compound 1 (Fig. 1).

Characterization of the phytotoxic compound. UV spectrum was recorded on a AGILENT 8453 UV-Visible spectrophotometer and IR spectrum on a JASCO FTIR4100 spectrometer. Low and high resolution EIMS were recorded on a MICROMASS AUTOSPEC mass spectrometer equipped with a OPUS data system. NMR data, including COSY, DEPT, HMQC, and HMBC, were taken on a VARIAN UNITY 500 spectrometer working at 500 $\mathrm{MHz}$ for proton and $125 \mathrm{MHz}$ for carbon. Chemical shifts are reported in ppm relative to the solvent $\left(\mathrm{CDCl}_{3}, \delta_{\mathrm{H}} 7.24\right.$, $\left.\delta_{\mathrm{C}} 77.0\right)$.

Biochemical and physiological characterization of a bacterial strain. Biochemical, physiological and molecular characteristics for identification of the bacteria were investigated according to "Current protocols in molecular biology" and "Chemical methods in prokaryotic systems" (Ausubel et al., 1995; Goodfellow and O'Donell, 1994). Gram staining was performed using a bioMérieux Gram Stain kit according to the instructions of the manufacturer. Cell morphology, flagella and gliding motility were studied using phase-contrast microscopy and transmission electron microscopy (H-600, Hitachi). The morphology of the strain was studied using a scanning electron microscopy (XL30 S FEG; Philips) (Kageyama et al., 2008; Ludmila et al., 2004). The physiological characteristics of the strain was examined by growing the isolate on 1/10 TSA agar at different temperatures $\left(5-50^{\circ} \mathrm{C}\right.$ at $5^{\circ} \mathrm{C}$ intervals $)$ and in $1 / 10$ TSB adjusted at different $\mathrm{pH}$ values $(5 \cdot 0-10 \cdot 0$ at $0 \cdot 5 \mathrm{pH}$ unit intervals). Hydrolysis of casein, Tween 20, Tween 80, esculin, urea, tyrosine, starch and nitrate reduction were studied on 1/10 TSA agar after a 7-day incubation at $30^{\circ} \mathrm{C}$ according to standard methods (Lanyi, 1987; Smibert snd Krieg, 1994). Enzymatic activities and biochemical features were determined using API ZYM and API ID32E kits as recommended by the manufacturer (bioMérieux) except that kits were incubated for 4 hours and 2 days at $30^{\circ} \mathrm{C}$, respectively. Analysis of fatty acid methyl esters was performed according to the instructions of the Microbial Identification System (MIDI; Microbial ID, Inc.). Analyses of polar lipids and isoprenoid quinones were carried out using the standard methods (Komagata \& Suzuki, 1987; Minnikin et al., 1984). The DNA G+C content was determined using a HPLC fitted with a reversed-phase column (GROM-SIL 100 ODS-2FE, GROM) (Tamaoka and Komagata, 1984).

Phylogenetic analysis of 16S rRNA gene sequence. The $16 \mathrm{~S}$ rRNA gene sequences was amplified from the purified genomic DNA by using a set of primers 27F (5'-AGAGTTTGATCMTGGCTCAAG-3') and 1492R (5'-GGYTACCTTGTTACGACTT-3') (Lane, 1991). The purified PCR product was sequenced by GenoTech Inc. (Daejeon, Korea). The 16S rRNA gene sequence was compiled using SeqMan software (DNASTAR) and that was compared with the sequences of related type strains, obtained from the GenBank database. The sequences were aligned using CLUSTAL_X program (Thompson et al., 1997) and phylogenetic trees were constructed by neighbor-joining distance method using Mega4 program with bootstrap values based on 1000 replications (Felsenstein, 1985; Saitou and Nei, 1987; Tamura et al., 2007). Gaps were edited using the BioEdit program (Hall, 1999). The evolutionary distances were calculated using the Kimura two-parameter model (Kimura, 1983).

\section{Results}

Isolation and culture of the bacteria with seed germination inhibitory activity. Among 300 bacterial strains tested for inhibition of radish germination, the culture filtrate of five strains had the inhibitory activity and the strain YC6002 isolated from the root of Korean turf grass had over $80 \%$ of inhibitory activity (Table 1 ). To select 
Table 2. Effect of culture filtrate of Arthrobacter humicola YC6002 with different culture period in 1/10 TSB on the germination inhibition of radish seeds

\begin{tabular}{|c|c|c|c|c|c|}
\hline \multirow{3}{*}{$\begin{array}{c}\text { Culture } \\
\text { period } \\
(\mathrm{hrs})\end{array}$} & \multicolumn{5}{|c|}{ Inhibition of radish seed germination $(\%)^{\mathrm{a}}$} \\
\hline & \multicolumn{5}{|c|}{ Days } \\
\hline & 1 & 2 & 3 & 4 & 5 \\
\hline 0 & 0 & 20.0 & $13.3 \pm 11.5$ & $6.6 \pm 11.5$ & 0 \\
\hline 24 & 0 & $66.6 \pm 11.5$ & 40.0 & 20.0 & 20.0 \\
\hline 48 & 0 & $66.6 \pm 11.5$ & $66.6 \pm 11.5$ & 60.0 & 60.0 \\
\hline 60 & 0 & $46.6 \pm 11.5$ & $33.3 \pm 23.0$ & $13.3 \pm 11.5$ & $13.3 \pm 11.5$ \\
\hline 72 & 0 & $60.0 \pm 20.0$ & $46.6 \pm 11.5$ & $46.6 \pm 11.5$ & $46.6 \pm 11.5$ \\
\hline
\end{tabular}

${ }^{\mathrm{a}}$ The culture filtrate was used to test the radish seed germination inhibitory activity. Five seeds of radish in three replications were placed on a piece of sterile Kim-Wipe tissue $(2 \times 2 \mathrm{~cm})$ in a plastic plate loaded with $0.5 \mathrm{ml}$ culture filtrate for 5 days under fluorescent light.

culture media for mass production of the germination inhibitory compound, six different culture media were tested. The rate of germination of radish seeds in the culture filtrate of $1 / 10$ TSB was higher than any other culture filtrate of TSB, Czapek-dox broth, but the filtrate of M523, MMC and R2A had no inhibition activity (data not shown). The strain YC6002 was cultured in 1/10 TSB for 3 days and the seed germination inhibitory activity was investigated by using culture filtrates of different time period ( 24 h, $48 \mathrm{~h}, 60 \mathrm{~h}$ and $72 \mathrm{~h}$ ). Results suggested that culture filtrate of 2-5 day old bacterial strain had over $60 \%$ inhibition of seed germination, the 48 hours old culture filtrate, however, revealed the most inhibition towards seed

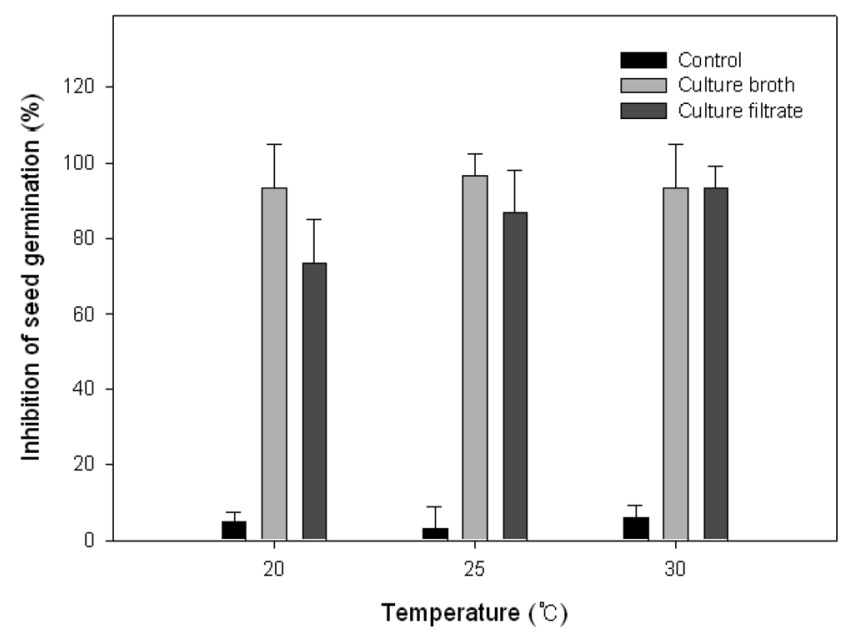

Fig. 2. Effect of culture temperatures on the inhibition of radish seed germination by Arthrobacter humicola YC6002 in 1/10 TSB on rotary shaker $(180 \mathrm{rpm}, 72 \mathrm{~h})$. Seed germination inhibitory test was performed at $25^{\circ} \mathrm{C}$ for $72 \mathrm{hrs}$. Vertical bars on columns indicate standard errors. germination. However, the inhibition ratio was decreased below $40 \%$ after 3 days in the culture filtrate of $24 \mathrm{~h}$ and 60 $\mathrm{h}$. The culture filtrates of $72 \mathrm{~h}$ showed less activity comparing to that of $48 \mathrm{hr}$ (Table 2). Effect of different culture temperatures of the strain YC6002 on the inhibition of radish seed germination was investigated. The ratio of germination inhibition was over $70 \%$ in both culture broth and filtrate of the strain at $20^{\circ} \mathrm{C}, 25^{\circ} \mathrm{C}$ and $30^{\circ} \mathrm{C}$. There was no significant difference in the inhibition activity of culture broth containing bacterial cells cultured at $20^{\circ} \mathrm{C}, 25^{\circ} \mathrm{C}$ and $30^{\circ} \mathrm{C}$ with the rates of $92 \%, 95 \%$ and $88 \%$, respectively. However, in case of culture filtrate, the inhibition rate was highest in the culture filtrate incubated at $30^{\circ} \mathrm{C}$ for $72 \mathrm{~h}$ with the rate of $92 \%$ (Fig. 2).

Characterization of the phytotoxic compound. The phytotoxic compound (1) $55 \mathrm{mg}$ was purified from the culture filtrate fraction YC-11 $(380 \mathrm{mg})$ prepared with mass cultured broth (54 L) of the strain YC6002 (Fig. 1). The structure of active compound KS1 was determined to have the molecular formula $\mathrm{C}_{9} \mathrm{H}_{10} \mathrm{O}_{2}$ based on high resolution EIMS data. This compound showed two methylene, one carbonyl, and six aromatic methine carbon signals in the DEPT spectra. Five protons at low field of ${ }^{1} \mathrm{H}$ NMR in compound 1 were assigned as one monosubstituted benzene by the ${ }^{1} \mathrm{H}-{ }^{1} \mathrm{H}$ COSY. Physico-chemical properties of compound 1 are summarized in Table 3 . These data were well consistent with those of authentic 3-phenylpropionic acid (hydrocinnamic acid) (Fig. 3). The active compound purified from the culture filtrate of the strain YC6002 showed seed germination inhibition by $53 \%, 93 \%$ and $100 \%$ at 500 ppm, 1,000 ppm and 10,000 ppm, respectively (Table 4).

Table 3. Physico-chemical properties of the active compound (1) purified from culture filtrate of Arthrobacter humicula YC6002 with seed germination inhibitory activity

\begin{tabular}{ll}
\hline \hline Appearance & Colorless powder \\
Melting point $\left({ }^{\circ} \mathrm{C}\right)$ & $48-49$ \\
Molecular formula & $\mathrm{C}_{9} \mathrm{H}_{10} \mathrm{O}_{2}$ \\
Molecular weight & $150\left[\mathrm{M}^{+}\right.$ \\
HREIMS $(\mathrm{m} / \mathrm{z})$ & Found 150.0702 \\
& Calcd. 150.0680 \\
$\mathrm{UV} \lambda_{\max }(\mathrm{MeOH}) \mathrm{nm}$ & 212,265 \\
$\mathrm{IR} v_{\max }(\mathrm{thin} \mathrm{film}) \mathrm{cm}^{-1}$ & $3332,1698,1454,1301,1219$ \\
$\mathrm{TLC}\left(\mathrm{R}_{\mathrm{f}}\right)^{*}$ & 0.67 \\
${ }^{1} \mathrm{H} \mathrm{NMR}\left(\mathrm{CDCl}_{3}\right)$ & $\delta 10.41(1 \mathrm{H}, \mathrm{brs}), 7.38-7.19(5 \mathrm{H}, \mathrm{m}), 2.99$ \\
& $(2 \mathrm{H}, \mathrm{t}), 2.69(2 \mathrm{H}, \mathrm{t})$ \\
& $\delta 179.0,139.9,128.4(\mathrm{x} 2), 128.1(\mathrm{x} 2)$, \\
& $126.2,35.6,30.6$
\end{tabular}

"Silica gel $60 \mathrm{~F}_{254}$ (Merck), EtOAc-n-hexane 1:1. 


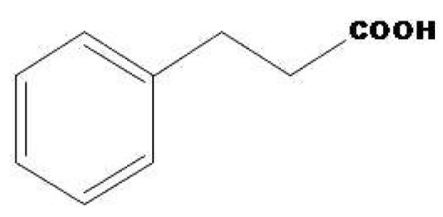

Fig. 3. The chemical structure of 3-phenylpropionic acid isolated from the culture filtrate of Arthrobacter humicola YC6002.

Table 4. Effect of purified compound (KS1) from the culture filtrate of Arthrobacter humicola YC6002 on the inhibition of germination and shoot growth of radish seeds

\begin{tabular}{ccc}
\hline $\begin{array}{c}\text { Concentration } \\
(\mathrm{ppm})^{\mathrm{a}}\end{array}$ & $\begin{array}{c}\text { Inhibition of radish } \\
\text { seed germination }(\%)^{\mathrm{b}}\end{array}$ & Shoot length $(\mathrm{mm})$ \\
\hline 0 & 0 & $15.6 \pm 0.5$ \\
100 & $13.3 \pm 0.6$ & $17.3 \pm 0.3$ \\
500 & $53.3 \pm 2.1$ & $4.2 \pm 0.4$ \\
1,000 & $93.3 \pm 1.5$ & 0 \\
10,000 & 100 & 0 \\
\hline
\end{tabular}

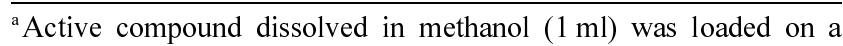
piece of sterile filter paper $(2 \times 2 \mathrm{~cm})$.

${ }^{\mathrm{b}}$ One $\mathrm{ml}$ of methanol dissolved with active compound was loaded on the piece of sterile filter paper $(2 \times 2 \mathrm{~cm})$ and dried. Five seeds of radish in 3 replications were placed on the filter paper soaked with $1 \mathrm{ml}$ of distilled water in a plastic plate for 5 days at $25^{\circ} \mathrm{C}$ under fluorescent light.

Identification of the strain YC6002. The bacterial strain YC6002 with germination inhibitory activity of radish seeds was isolated from the root of Z. japonica and identified. Based on biochemical, physiological characteristics and 16S rRNA gene sequence analysis, the strain YC6002 was identified as Arhthrobacter humicola (Fig. 4). Cells were Gram-positive, non-motile and long and short rodshaped $(0.3-0.5 \times 2.5-4.0 \mu \mathrm{m})$. The colonies grown on 0.1 TSA agar plates for three days were smooth, circular, and whitish very shine yellow in color, 1-2 $\mathrm{mm}$ in diameter. Casein, gelatin, starch and tyrosine are hydrolyzed. Tween 20 and 80, esculin, carboxylmethylcellulose and urea are not hydrolysed. Nitrate is not reduced to nitrite and nitrogen. In API ZYM kit, alkaline phosphatase, leucine arylamidase and valine arylamidase activities are present; esterase (C-4), esterase lipase (C-8), leucine arylamidase, valine arylamidase, cystine arylamidase, $\alpha$-mannosidase, $\alpha$-glucosidase, $\alpha$-galactosidase, $\beta$-galactosidase are present; acid phosphatase, naphtol-AS-BI-phosphohydrolase, trypsin, lipase (C-14), lipase (C-14), $\alpha$-fucosidase, $\beta$-glucuronidase and $\beta$-glucosidase are negative. MK- 8 is the major respiratory menaquinone. The major polar lipids are phosphatidylethanolamine, phosphatidylglycerol, phosphatidyl- $N$ methylethanolamine and ninhydrin-phosphatidylglycerol. The $\mathrm{G}+\mathrm{C}$ content of the genomic DNA was $61.2 \mathrm{~mol} \%$. The major cellular fatty acids in strain YC6002 included $\mathrm{C}_{14: 0}$ iso (1.0\%), $\mathrm{C}_{14: 0}(1.2 \%), \mathrm{C}_{15: 0}$ iso (4.7\%), $\mathrm{C}_{15: 0}$ anteiso (36.5\%), $\mathrm{C}_{16: 1}$ iso (5.0\%), $\mathrm{C}_{17: 0}$ iso (1.2\%), $\mathrm{C}_{17: 0}$ anteiso $(15.0 \%)$ and $\mathrm{C}_{18: 0}(8.8 \%)$. Comparative $16 \mathrm{~S}$ rRNA gene sequence analysis showed that the strain was most closely

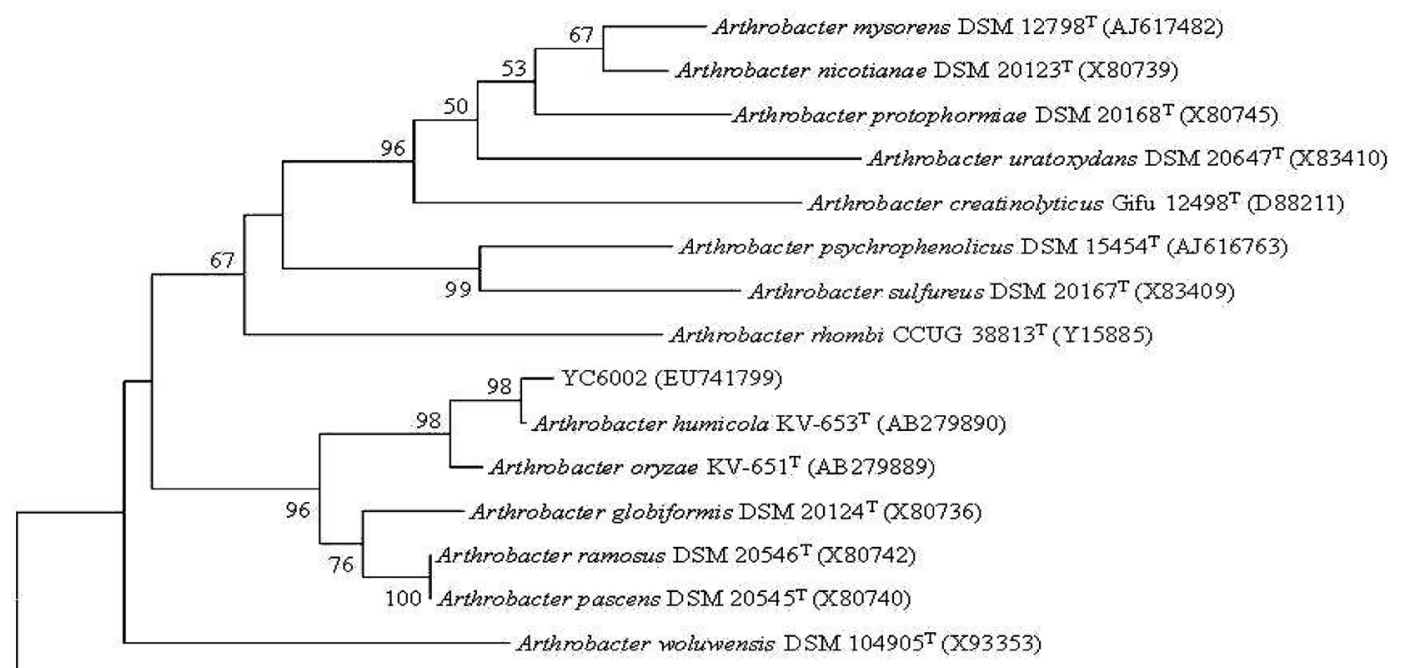

Arthrobacter koreensis CA15-9 (AY116497)

Fig. 4. Phylogenetic tree constructed from the comparative analysis of 16S rRNA gene sequences showing the relationships of strain YC6002 with other related species. This phylogenetic tree was constructed by using the neighbor-joining method and Jukes \& Cantor evolutionary distance matrix data obtained from unambiguous aligned nucleotides. Bootstrap values (expressed as percentage of 1000 replications) greater than $50 \%$ are shown at the branch points. Bar, 1 substitution per 100 nucleotide position. 
related to $A$. humicola $\mathrm{KV}-653^{\mathrm{T}}(99.7 \%)$, A. oryzae $\mathrm{KV}-651^{\mathrm{T}}$ (99.2\%), A. globiformis DSM20124 $4^{\mathrm{T}}(98.5 \%)$ and $A$. ramosus DSM20546 ${ }^{\mathrm{T}}$ (98.3) (Fig. 4).

\section{Discussion}

The endophytic bacterium, YC6002 with seed germination inhibitory activity was isolated from the root of $Z$. japonica and identified as A. humicola. Arthrobacter species are wide-spread in soil, air, ice cave, clinical sources and plant tissues (Aravind et al., 2009; Guido et al., 1996; Lee et al., 2003; Rosa et al., 2004). Some strains of Arthrobacter species have been reported to degrade a wide range of xenobiotic substances such as fluorene, isocarbophos and 4-fluorophenol (Casellas et al., 1997; Ferreira et al., 2008). In addition, many strains of Arthrobacter species were also known to inhibit plant growth and seed germination which were used for biological control of plant diseases (BarrowsBroaddus et al., 1985; Chung et al., 2008; Mundt and Hinkle, 1976; Pusey, 1997). The strain YC6002 inhibited seed germination and stem growth of radish by producing a phytotoxic compound. The strain of $A$. pascens was reported to inhibit plant and root growth by producing inhibitors of auxin and gibberellin (Edmund et al., 1971). On the contrary, some strains of $A$. ilicis and $A$. oxydans were used for biological control against Helminthosporium solani, a causal agent of potato silver scurf (Elson et al., 1997; Michaud and Martinez, 2002). Sziderics et al. (2007) suggested that a strain of $A$. oxydans inhabited within pepper plants as endophytic bacterium produced indole acetic acid (IAA) and 1-aminocyclopropane-1-carboxylic acid deaminase (ACCD) which were known to enhance plant growth and contributed to a biotic stress adaptation in host plants. Although many strains of Arthrobacter spp. are worth as the biological control agent, the phytotoxic activity was hardly reported. In a certain endophytic bacteria, both phytotoxic and antifungal compounds were produced (Chung et al., 2008). A. humicola was also isolated from a paddy soil sample but no phytotoxic activity was reported in this strain (Kageyama et al., 2008).

The chemical structure of a compound in culture filtrate of the strain YC6002 with seed germination inhibitory activity was determined to be 3-phenylpropionic acid (hydrocinnamic acid), which was rarely produced as a microbial metabolite. Phenylpropionic acid is a member of the phenylpropanoid family, comprising a wide variety of C3-C6 compounds synthesized by plants from phenylalanine and is important in the synthesis of flavonoids, insect repellents, UV protectants and signal molecules for defense mechanisms (Hahlbrock and Scheel, 1989). The phenolic compound 3-phenlypropionic acid is known to be inhibitory to germinating seeds or growing plants (Jing and
Yoshihisa, 1994; Williams and Hoagland, 1982). Moss et al. (1970) found that hydrocinnamic acid and cinnamic acid were produced from cultures of Clostridium sporogenes when cell suspensions exposed to 1-phenylalanine. Chamkha et al. (2001) reported that the strain of Clostidium bifermentans isolated from olive mill wastewaters produced 3phenylpropionic acid by conversion of cinnamic acid. The 3-phenylpropionic acid was also found in ruminal fluid by chemical reduction of dietary phenolic monomers by ruminal bacteria (Cremin et al., 1994). It has been recently reported that an antagonistic strain of Burkholderia spp. isolated from the Naju area produces antifungal compounds composed of phenylacetic acid, hydrocinnamic acid, 4hydroxyphenylacetic acid and 4-hydroxyphenylacetate methyl ester (Mao et al., 2006). A strain of Streptomyces sp. isolated from laterite soil also has been found to produce 3phenylpropionic acid and showed antimicrobial activity against different bacteria and Fusarium udum causing wilt disease in pigeon pea (Narayana et al., 2007). Recently, aromatic compounds extracted from fresh leaves and twigs of Oxalis pes-caprae including cinnamic acid esters have been shown to be phytotoxic to the germination and growth of lettuce. The inhibitory activity of some of these compounds was higher than that of pendimethalin, a commercial pre-emergence herbicide (DellaGreca et al., 2009). The phytotoxic compound produced by the strain of A. humicola YC6002, 3-phenylpropionic acid, could be developed for an environmentally safe herbicide with the further study on its chemical derivatization.

\section{Acknowledgements}

This research was supported by the project for Regional Strategic Industry Development (70001276), Ministry of Knowledge Economy, Korea and the BK 21 program (20072009), Ministry of Education, Science and Technology, Korea.

\section{References}

Andreote, F. D., de Araújo, W. L., de Azevedo, J. L., van Elsas, J. D., da Rocha, U. N. and van Overbeek, L. S. 2009. Endophytic colonization of potato (Solanum tuberosum L.) by a novel competent bacterial endophyte, Pseudomonas putida P9, and its effect on associated bacterial communities. Appl. Environ. Microbiol. 75:3396-3406.

Aravind, R., Kumar, A., Eapen, S. J. and Ramana, K. V. 2009. Endophytic bacterial flora in root and stem tissues of black pepper (Piper nigrum L.) genotype: isolation, identification and evaluation against Phytophthora capsici. Lett. Appl. Microbiol. 48:58-64.

Ausubel, F. M., Brent, R., Kingston, R. E., Moore, D. D., 
Seidman, J. G, Smith, J. A. and Struhl, K. 1995. Current protocols in molecular biology, New York: Wiley.

Azevedo, J. L., Maccheroni, J. Jr., Pereira, O. and Ara, W. L. 2000. Endophytic microorganisms: a review on insect control and recent advances on tropical plants. Electr. J. Biotech. 3:4065.

Beck, H. C., Hansen, A. M. and Lauritsen, F. R. 2003. Novel pyrazine metabolites found in polymyxin biosynthesis by Paenibacillus polymyxa. FEMS Microbiol. Lett. 220:67-73.

Bender, C. L., Alarcon-Chaidez, F. and Gross, D. C. 1999. Pseudomonas syringae phytotoxins: mode of action, regulation, and biosynthesis by peptide and polyketide synthetases. Microbiol. Mol. Biol. Rev. 63:266-292.

Brooks, D. S., Gonzalez, C. F., Appel, D. N. and Filer, T. H. 1994. Evaluation of endophytic bacteria as potential biological control agents for oak wilt. Biol. Control 4:373-381.

Barrows-Broaddus, J., Dwinell, L. D. and Kerr, T. J. 1985. Evaluation of Arhtrobacter sp. for biological control of the pitch canker fungus (Fusarium moniliforme var. subglutinans) on slash pines. Can. J. Microbiol. 31:888-892.

Carvalho, D. D. C., Oliveira1, D. F., Corrêa, R. S. B., Campos, V. P., Guimarães, R. M. and Coimbra, J. L. 2007. Rhizobacteria able to produce phytotoxic metabolites. Braz. J. Microbiol. 38:759-765

Casellas, M., Grifoll, M., Ayona, J. M. and Solanasi, A. M. 1997. New metabolites in the degradation of fluorene by Arthrobacter sp. strain F101. Appl. Environ. Microbiol. 63:819-826.

Chamkha, M., Patel, B. K. C., Garcia, J and Labat, M. 2001. Isolation of Clostridium bifermentans from oil mill wastewaters converting cinnamic acid to 3-phenylpro pionic acid and emendation of the species. Anaerobe 7:189-197.

Chung, B. S., Aslam, Z., Kim, S. W., Kim, G. G., Kang, H. S., Ahn, J. W. and Chung, Y. R. 2008. A bacterial endophyte, Pseudomonas brassicacearum YC5480 isolated from the root of Artemisia sp. producing antifungal and phytotoxic compounds. Plant Pathol. J. 24:461-468.

Cremin, J. D. Jr., Drackley, J. K., Grum, D. E., Hansen, L. R. and Fahey, G. C. Jr. 1994. Effects of reduced phenolic acids on metabolism of propionate and palmitate in bovine liver tissue in vitro. J. Dairy Sci. 77:3608-3617.

DellaGreca, M., Previtera, L., Purcaro, R. and Zarrelli, A. 2009. Phytotoxic aromatic constituents of Oxalis pescaprae. Chem. Biodivers. 6:459-465.

Duijff, B. J., Gianinazzi-Pearsonand, V. and Lemanceau, P. 1997. Involvement of the outer membrane lipopolysaccharides in the endophytic colonization of tomato roots by biocontrol Pseudomonas fluorescens strain WCS417r. New. Phytol. 135:325334.

Edmund, S., Maria, K. and Krystyna, K. 1971. Production of inhibitors of auxin and gibberellin induced growth of plants by Arthrobacter pascens. Acta. Microbiol. Pol. 3:85-87.

Elson, M. K., Schisler, D. A. and Bothast, R. J. 1997. Selection of microoraganisms for biological control of silver scurf (Helminthosporium solani) of potato tubers. Plant Dis. 81:647-652.

Felsenstein, J. 1985. Confidence limits on phylogenies: an approach using the bootstrap. Evolution 39:783-791.
Ferreira, M. I. M., Marchesi, J. R. and Janssen, D. B. 2008. Degradation of 4-fluorophenol by Arthrobacter sp. strain IF1. Appl. Microbiol. Biotechnol. 78:709-717.

Goodfellow, M. and O'Donell, A. G 1994. Chemical methods in prokaryotic systems. John Willey \& Sons, New York, N. Y., $575 \mathrm{pp}$.

Guido, F., Roger, A. H., Kathrya, A. B., Gagy, E. P., Georges, W. and Matthew, D. C. 1996. Isolation of Arthrobacter spp. from clinical specimens and description of Arthrobacter cumminsi sp. nov. and Arthrobacter woluwensis sp. nov. J. Clin. Microbiol. 34:2356-2363.

Hahlbrock, K. and Scheel, D. 1989. Physiology and molecular biology of phenyl prorapanoid metabolism. Annu. Rev. Plant Physiol. Plant Mol. Biol. 40:347-369.

Hall, T. A. 1999. BioEdit: a user-friendly biological sequence alignment editor and analysis program for Windows 95/98/ NT. Nucleic Acids Symp. Ser. 41:95-98.

Jing, Q. Y. and Yoshihisa, M. 1994. Phytotoxic substances in root exudates of cucumber (Cucumis sativus L.). J. Chem. Ecol. 20:21-31.

Kageyama, A., Morisaki, K., $\overline{\mathrm{O}}$ mura, S. and Takahash, Y. 2008. Arthrobacter oryzae sp. nov. and Arthrobacter humicola sp. nov.. Int. J. Syst. Evol. Microbiol. 58:53-56.

Kimura, M. 1983. The neutral theory of molecular evolution. Cambridge: Cambridge University Press.

Komagata, K. and Suzuki, K. 1987. Lipid and cell-wall analysis in bacterial systematics. Methods Microbiol. 19:161-208.

Lane, D. J. 1991. 16S/23S rRNA sequencing. In Nucleic Acid Techniques in Bacterial Systematics, pp. 115-175. Edited by E. Stackebrandt \& M. Goodfellow. New York: Wiley.

Lanyi, B. 1987. Classical and rapid identification methods for medically important bacteria. Methods Microbiol. 19:1-67.

Lee, J. S., Lee, K. C., Pyun, Y. R. and Bae, K. S. 2003. Arthrobacter koreensis sp. nov., a novel alkalitolerant bacterium from soil. Int. J. Syst. Evol. Microbiol. 53:1277-1280.

Lee, S. O., Choi, G. J., Choi, Y. H., Jang, K. S., Park, D. J., Kim, C. J. and Kim, J. C. 2008. Isolation and characterization of endophytic actinomycetes from Chinese cabbage roots as antagonists to Plasmodiophora brassicae. J. Microbiol. Biotechnol. 18:1741-1746.

Liu, C. H., Chen, X., Liu, T. T., Lian, B., Gu, Y., Caer, V., Xue, Y. R. and Wang, B. T. 2007. Study of the antifungal activity of Acinetobacter baumannii LCH001 in vitro and identification of its antifungal components. Appl. Microbiol. Biotechnol. 76:459-466.

Ludmila, K., Peter, S., Eva, D., Cathrin, S., Ivo, S., Jiri, N., Zbynek, Z. and Miroslav, N. 2004. Arthrobacter nitroguajacolicus sp. nov., a novel 4-nitroguaiacol-degrading actinobacterium. Int. J. Syst. Evol. Microbiol. 54:773-777.

Mao, S., Lee, S. J., Hwangbo, H., Kim, Y. W., Park, K. H., Cha, G. S., Park, R. D. and Kim, K. Y. 2006. Isolation and characterization of antifungal substances from Burkholderia sp. culture broth. Curr. Microbiol. 53:358-364.

Michaud, M. and Martinez, C. 2002. Selection of antagonist microorganisms against Helminthosporium solani, causal agent of potato silver scurf. Plant Dis. 86:717-720. 
Moss, C. W., Lambert, M. A. and Goldsmith, D. J. 1970. Production of hydrocinnamic acid by Clostridia. Appl. Microbiol. 19:375-378.

Miller, C. M., Miller, R. V., Garton-Kenny, D., Redgrave, B., Sears, J., Condron, M. M., Teplow, D. B. and Strobel, G A. 1998. Ecomycins, unique antimycotics from Pseudomonas viridiflava. J. Appl. Microbiol. 84:937-944.

Minnikin, D. E., O'Donell, A. G., Goodfellow, M. and Alderson, G. 1984. An integrated procedure for the extraction of bacterial isoprenoid quinones and polar lipids. J. Microbiol. Methods 2:233-241.

Mundt, J. O. and Hinkle, N. F. 1976. Bacteria within ovules and seeds. Appl. Environ. Microbiol. 32:694-698.

Narayana, K. J., Prabhakar, P., Vijayalakshmi, M., Venkateswarlu, Y. and Krishna, P. S. 2007. Biological acitivity of phenylpropionic acid isolated from a terrestrial Streptomycetes. Pol. J. Microbiol. 56:191-197.

Patel, A., Deshattiwar, M., Chaudhari, B. and Chincholkar, S., 2009. Production, purification and chemical characterization of the catecholate siderophore from potent probiotic strains of Bacillus spp.. Bioresour. Technol. 100:368-373.

Pusey, P. L. 1997. Crab apple blossoms as a model for research on biological control of fire blight. Phytopathology 87:10961102.

Ramasamy, K., Lim, S. M., Bakar, H. A., Ismail, N., Ismail, M. S. Ali, M. F., Weber, J. F. and Cole, A. L. J. 2009. Antimicrobial and cytotoxic activities of malaysian endophytes. Phytother. Res. 24:640-643.

Rosa, M., Peter, S., Cathrin, S. and Anne-Monique, G 2004. Arthrobacter psychrophenolicus sp. nov., isolated from an alpine ice cave. Int. J. Syst. Evol. Microbiol. 54:2067-2072.

Rosenblueth, M. and Martínez-Romero, E. 2006. Bacterial endophytes and their interactions with hosts. Mol. Plant-Microbe Interact. 19:827-837.

Ryan, R. P., Germaine, K., Franks, A., Ryan, D. J. and Dowling, D. N. 2008. Bacterial endophytes: recent developments and applications. FEMS Microbiol. Lett. 278:1-9.

Ryu, C. M., Farag, M. A., Hu, C. H., Reddy, M. S., Wei, H. X., Pare, P. W. and Kloepper, J. W. 2003. Bacterial volatiles promote growth in Arabidopsis. Proc. Nat. Acad. Sci. USA. 100:4927-4935.
Saitou, N. and Nei, M. 1987. The neighbor-joining method: a new method for reconstructing phylogenetic trees. Mol. Biol. Evol. 4:406-425.

Siciliano, S. D., Fortin, N., Mihoc, A., Wisse, G, Labelle, S., Beaumier, D., Ouellette, D., Roy, R., Whyte, L. G., Bankes, M. K., Schwab, P., Lee, K. and Greer, C. W. 2001. Selection of specific endophytic bacterial genotypes by plants in response to soil contamination. Appl. Environ. Microbiol. 67:2469-2475.

Singh, P. P., Shin, Y. C., Park, C. S. and Chung, Y. R. 1999. Biological control of Fusarium wilt of cucumber by chitinolytic bacteria. Phytopathology 89:92-99.

Smibert, R. M. and Krieg, N. R. 1994. Phenotypic characterization. In Methods for General and Molecular Bacteriology, pp. 607-654. Edited by P. Gerhardt. Washington D.C. Amer. Soc. Microbiol.

Strobel, G and Daisy, B. 2003. Bioprospecting for microbial endophytes and their natural products. Microbiol. Mol. Biol. Rev. 67:491-502.

Strobel, G., Daisy, B., Castillo, U. and Harper, J. 2004. Natural products from endophytic microorganisms. J. Nat. Prod. 67:257-268.

Sziderics, A. H., Rasche, F., Trognitz, F., Sessitsch, A. and Wilhelm, E. 2007. Bacterial endophytes contribute to abiotic stress adaptation in pepper plants (Capsium anпuиm L.). Can. J. Microbiol. 53:1195-1202.

Tamaoka, J. and Komagata, K. (1984). Determination of DNA base composition by reversed-phase high-performance liquid chromatography. FEMS Microbiol. Lett. 25:125-128.

Tamura, K., Dudley, J., Nei, M. and Kumar, S. 2007. MEGA4: Molecular Evolutionary Genetics Analysis (MEGA) software version 4.0. Mol. Biol. Evol. 24:1596-1599.

Thompson, J. D., Gibson, T. J., Plewniak, F., Jeanmougin, F. and Higgins, D. G. 1997. The CLUSTAL_X Windows interface: flexible strategies for multiple sequence alignment aided by quality analysis tools. Nucleic Acids Res. 25:4876-4882.

Vurro, M., Boari, A., Evidente, A., Andolfi, A. and Zermane, N. 2009. Natural metabolites for parasitic weed management. Pest. Manag. Sci. 65:556-571.

Williams, R. D. and Hoagland, R. E. 1982. The effect of naturally occurring phenolic compounds. Weed Sci. 30:206-212. 